\title{
Feline Reticulum Cell Sarcoma
}

National Cancer Institute

\section{Source}

National Cancer Institute. Feline Reticulum Cell Sarcoma. NCI Thesaurus. Code C135008.

Reticulum cell sarcoma that occurs in a cat. 